\title{
ARCHITECTURE OF DEPTH: GRAVICELLS AS A CRITICAL SPATIAL PRACTICE IN THE $21^{\text {ST }}$ CENTURY (1) Jung E. CHOI*
}

Received: 26.09.2016; Final Text: 17.04.2017

Keywords: The expanded field of art; architecture and technology; twenty-first century media; alternative spatiality; depth; phenomenological reconstruction.

1. A shorter version of this paper was presented at The $5^{\text {th }}$ International Computer Art Congress (2016) in Paris, France.

\footnotetext{
* Department of Art, Art History and Visual Studies, Duke University, Durham, USA
}

\section{INTRODUCTION}

This essay explores Gravicells - Gravity and Resistance (2004), by Seiko Mikami and Sota Ichigawa as an architectural experimentation that perfectly demonstrates the key potentials of the twenty-first century media operating at the intersection of art, architecture, and technology. It allows us to affectively experience virtual dimensions of the world through embodied experiences facilitated by the architectural site. Mikami and Ichigawa first exhibited Gravicells at Yamaguchi Center for Arts and Media (YCAM), Japan in 2004. In this work, glowing projected lines are distributed over the surface of the sensor-fitted floor and the visitors' physical variations such as velocity, direction, movement and weight can manipulate their visual organizations associated with sounds. In this experience, visitors are able to sensibly experience the correlation between their bodies and spatial organizations. It is a realization of the expanded field of art and architecture that produces a new perception that allows us to discover the invisible or virtual dimension of the world.

According to Rendell $(2008,44)$, an architectural designer and historian, there has been an "explosion" of art and architectural practices. Rendell develops an understanding of art as processual engagement with production and reception that operate simultaneously within multiple expanded disciplines, with artists "operating at sites within, at the edge of, between and across different disciplinary territories." As Hawkins (2014) also notices, not only does she use a spatial metaphor as a means of understanding interdisciplinarity, but she also implicates spatial approaches and subjects as one of the disciplinary fields with which art engages. Rendell $(2006,6)$ describes work that lies at the intersection of art and architecture as "critical spatial practice." In this essay, this term is extended to indicate critical spatial practice that allows us to describe work that transgresses the limits of art and architecture through incorporation of technology. As Grosz $(2001,75)$ argues, perhaps the most striking 
Figure 1. An Installation View of Gravicells, Seiko Mikami + Sota Ichikawa, Photo: Ryuichi Maruo (YCAM), Courtesy of Yamaguchi Center for Arts and Media (YCAM), 2004.
Figure 2. An Installation View of Gravicells, Seiko Mikami + Sota Ichikawa, Photo: Ryuichi Maruo (YCAM), Courtesy of Yamaguchi Center for Arts and Media (YCAM), 2004.
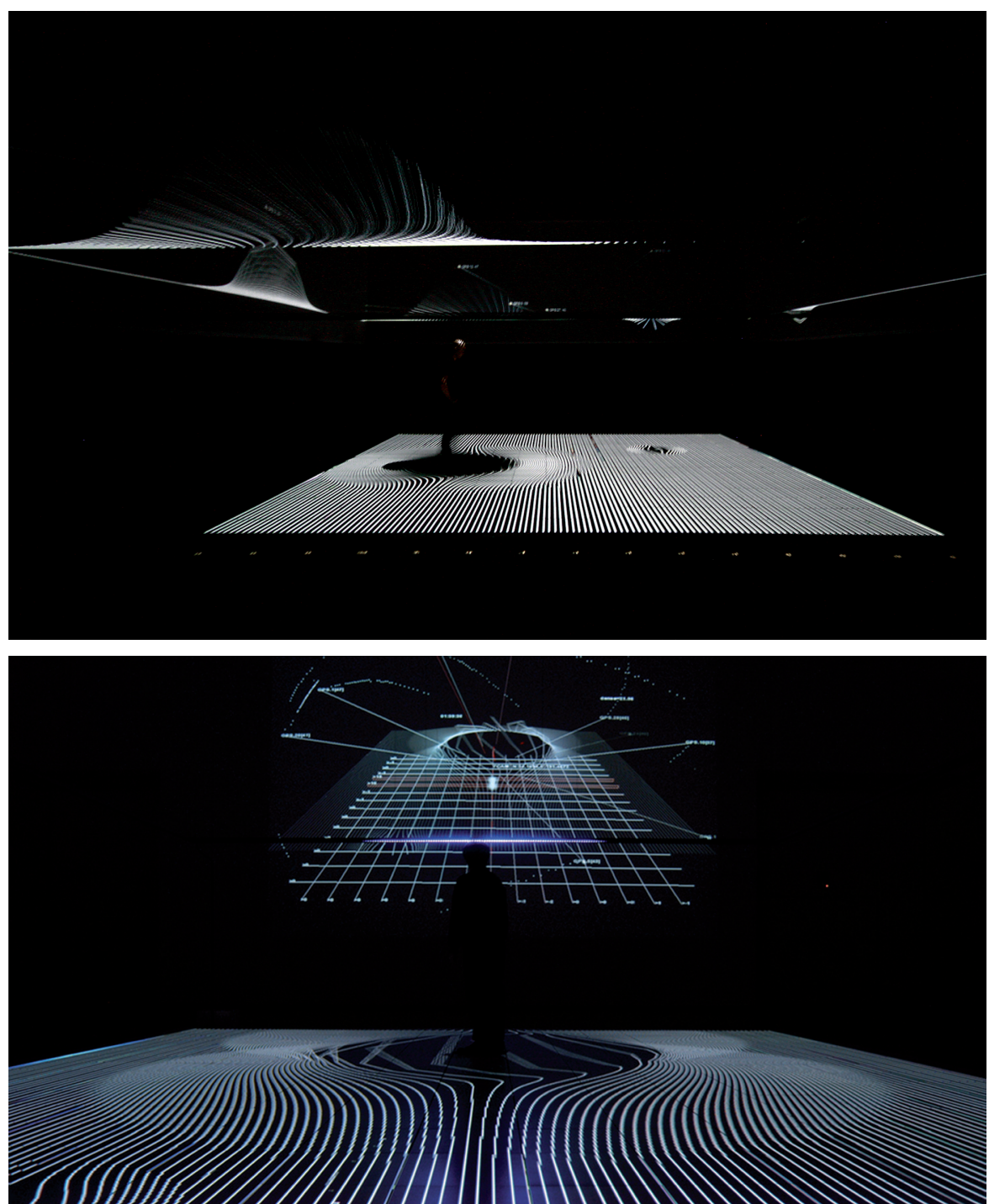

transformation heralded by digital technologies in the twenty-first century is "the change in our perceptions of materiality, space, and information, which is bound directly or indirectly to affect how we understand architecture, habitation, and the built environment." Witnessing the dynamic encounters, the intersections of art, architecture and technology strive to generate creative encounters that allow us to renew and change our thinking of spatiality.

As a critical spatial practice, Gravicells epitomizes points of overlap and spaces of cooperation between art, architecture, and technology that operate as experiential interfaces that place the focus on the virtual and dynamic dimensions of the world. Massumi $(2007,7)$ argues that art "is the technique of making vitality affect felt, of making an explicit experience of what otherwise slips behind the flow of action and is only implicitly felt. It is making the imperceptible appear." In his account, art is a medium of the virtual; it engages with the virtual dimensions of our experience, playing precisely at the juncture between the invisible and the visible as it makes these potential but invisible dimensions sensibly appear in our experience. Of the twenty-first century media, Hansen $(2004 ; 2015)$ suggests that they 
have the capacity to broker a technical enlargement of the threshold of the present that comprises the very ground of our experience. As a tendency rather than a technical object or process, the twenty-first century media, by expanding our primary sensory contact with the world, allow humans to access "a domain of sensibility of the world that has remained largely invisible (though certainly not inoperative)." (Hansen, 2015, 6) Seamlessly (and invisibly) distributed throughout built environments, the twentyfirst century media construct a field of augmented sensibility of those environments as well as opening up access to the invisible and virtual dimensions of the world by expanding our primary sensory contact with the world.

While Hansen's (2015) account of the potential investment of the twentyfirst century media in the living present mostly implies a temporal expansion that permits access to imperceptible (or virtual) affective modalities in time, this study suggests that Gravicells, as an architectural setup of the twenty-first century media, achieves an ever-deepening correlation of the spatial and temporal dimensions, of our living present with the notion of depth. To clarify the complex dimensions of this spatiotemporality, this paper attempts to reconstruct the notion of depth in Merleau-Ponty's spatial theory as a spatiotemporal atmosphere that sustains the inter-implications between subject and world from which their relational boundaries emerge. Depth responds to the ontological issues involved in thinking space inter-relationally and offers a substantial understanding of the spatial structure of the present. Gravicells illustrates how the twenty-first century media, through a technological enlargement of the complex present that is both spatial and temporal, are able to materialize the virtual dimension of depth that usually operates beyond human perception.

The notion of depth further begs the exploration of a critical question implied in the practice of Gravicells as it radically reframes the sense of space. In particular, Gravicells grants its space a kind of agency or sensibility that materializes inter-relationships between bodies and space. It does so by immaterializing space as an emergent property that is always in the state of becoming through technological integration in its architectural environment. In this process, the perception of space becomes a creative and participatory activity. Space is never a pre-given entity; rather, it is a process of transformation that is constantly defined by bodily involvement. Space reveals itself in the primordial spatiality that grounds the interrelationship between the body and the world. This paper considers the primordial spatiality 'operational depth,' which is the worldly spatial structure that grounds the perception of depth in the first place. In much post-phenomenological work, depth has been considered as a dimension of human perception or as a subjective space. However, with the notion of operational depth, this study brings the focus back to the more fundamental spatiality that structures our sense of space in the first place.

In embodied experience, depth is animated by, and is an exhibition of, the process of reversibility that produces subjects and worlds through intertwining. This paper continues to analyze the experience in Gravicells focusing on structural entanglements clearly indicated in Merleau-Ponty's development of the notion of depth: between body and space, and between time and space. As a source of reversibility, depth escapes the binary relationships of the world, producing subjects and worlds only through intertwining. Each component that constructs our living-present has a 
chiasmatic relationship with others. While preserving its own dimension, a particular dimension is never complete until it manifests itself in relationship with the other dimensions. The sense of space in Gravicells only emerges from the interactions between the physicality of the body (its weight, velocity, and direction) and its environmental counterpart (gravity). While understanding the experience through the notion of depth suggests an intrinsic entanglement between the body and the world as well as between time and space, the study is able to point to the more situational and environmental qualities of the complex interactions between bodysubjects and the world.

\section{EXPLORING ALTERNATIVE SPATIALITY IN GRAVICELLS: OPERATIONAL DEPTH}

Upon entering the architectural setup of Gravicells, a participant finds a space filled with a multitude of glowing lines. As she cautiously steps onto the floor, the surrounding lines are pushed away, making room for her body, as if she is dipping her foot into water. The ordinary sense of bodily orientation is disrupted as space becomes warped, reacting to one's weight, velocity, and movement. The space is never preconditioned but continually transforms itself according to her physical variables. Before long, she learns to orient herself within this space that is in constant transformation. She feels the sense of connectedness between her bodily movements and the space; she even starts choreographing her movements with the space.

By inviting participants into a data-saturated environment that visualizes gravitational relations, Gravicells offers an affective experience of the intrinsic interconnectedness between space and participant's body. Space, in the experience of Gravicells, is not space in the traditional sense - a physical container or a conceived object that is static and accessible to measurement - but rather a mode of coexistence that is constantly in flux and scarcely accessible through any conceptual framework. By dematerializing Euclidean geometric space into an interactive, flexible, and emergent property, Gravicells materializes the primordial spatiality that grounds the crisscrossing between bodies and space. I call this primordial spatiality depth. Merleau-Ponty $(1968,298)$ writes that depth is "the most existential dimension", "the dimension of dimensions; it is the sine qua non of the world and Being." In his understanding, depth is fundamental - or, using his term, elemental - to every experience. Merleau-Ponty (1968) considers depth to be the primary spatiality that grounds experiences of the world. Depth designates the first dimension, where one experiences the distance between one's self and other things. By making things both connected and separated, depth constitutes a perceptual horizon that places the body with other things, as well as the world; this interconnection is indispensable to understanding depth. In other words, depth is a general milieu for the co-existence of the body and the world that provides us with a perceptual ground.

Reconstructing the notion of depth by Merleau-Ponty, in my study, depth is no longer treated as an abstract geometrical space that is indirectly inferred from two-dimensional retinal images; instead, it is the primary spatial medium that grounds the coexistence of the world. In terms of its basic constitution, depth comprises both distance and voluminosity; distance reveals the immediate link between the subject and the world, while voluminosity describes an atmospheric dimension that indicates the possibility of voluminous bodies involved in the world. As both an 
origin and a means of enveloping the subject in the world, depth is best understood as the general milieu or primary condition that grounds the continuous inter-implication between body, time and space; depth supports their envelopment, while they are fundamentally all structured in depth. Gravicells materializes the envelopments in embodied experience.

In Gravicells, the gravitational waves are technologically intensified and audio-visually manifested; it is a space in which gravity becomes sensibly accessible within our embodied experience. The artists designed the dynamic technological space of Gravicells based on the premise that gravity is not materialized without a counterforce (for example, resistance). The notion of gravity inherently indicates a sense of material interdependence between a subject and its environment. Gravity, first discovered by Newton (1687), is a force that directly acts between two bodies. In the law of gravity, space and time remain as absolute and independent realities regardless of any material body that acts upon them; the space of gravity is flat. However, Einstein (1920) replaced Newtonian gravity with general relativity, understanding gravity as a curvature of spacetime. For Einstein (1920), a massive body causes the surrounding spacetime to curve. This spacetime that manifests gravity contradicts Euclidean geometry. Einstein $(1920,8)$ explains: "The laws according to which material bodies are arranged in space do not exactly agree with the laws of space prescribed by the Euclidean geometry of solids. This is what is meant by the phrase 'a warp in space.'" Space and time in Einstein's universe are no longer flat (as implicitly assumed by Newton) but can be pushed and pulled, stretched and warped by matter. It is a field of tension. Gravity feels strongest where space-time is most curved, and it vanishes where space-time is flat. This is the core of Einstein's theory of general relativity, which is often summed up by the following words: "Matter tells space-time how to curve, and curved space-time tells matter how to move." (Overduin, 2007)

In Gravicells, the body creates a sensible curvature of space that lies in constant transformation. The curvature that is hardly perceived in our normal perception appears as a technologically visualized sphere around the body. By augmenting both our bodily ability to create a curvature in the dimension of space-time, and environmental affordances, Gravicells materializes the operation of space-time that is always in relationship with a massive body. While the dimension of space-time in Einstein's theory is only discovered in a system of coordination in which the body is located outside, depth in this study designates a voluminous atmosphere that encompasses the body. By discovering depth as the primordial spatiality, one can confirm the bodily situatedness (or bodily anchoring) of the world that is the precognitive background of any action or movement. In depth, space itself is not external to being. As Merleau-Ponty $(1968,178)$ says: "I live it from the inside, it encompasses me. After all, the world is all around me, not in front of me." The fundamental crisscrossing of the body and the world indicates the origin of the sense of depth. Depth both enables and sustains the embrace of "coexistence". As an operational spatiality that both connects and separates things in the world, depth is understood as a force that sustains their relations while also encompassing them. The notion of general relativity helps us understand a fundamental idea that space-time is always in a relationship with material bodies. However, moving forward from the theory of general relativity, Gravicells offers an experiential medium of depth in which the body is invited to create its own spatial level (2); rather than being placed outside the space-time continuum, the body enters into the voluminous space-time sphere. The
2. The constitution of a spatial level is simply one means of constituting an integrated world. This action points clearly to an experiential ground, a general setting in which the body can co-exist with the world. 
technologically augmented space-time of Gravicells indeed manifests a field of co-existence, or co-origination between the gravities of the bodies and the reflexes of the environment.

In Gravicells, interconnected sensors continuously measure the physical qualities of bodies such as the participants' weight, movements, and speed. On the basis of these physical measurements, the bodies continuously produce new spatial configurations. In -process of spatialization, -bodies and space co-originate from and define each other, and this co-origination is possible because they are both grounded in depth. The interchange between a participant's body and the environmental force creates a virtual sphere-like room that follows every movement and direction of the body. This is a space that can never be defined in terms of a subject and object relationship. Instead, it has a peculiar intermediary status. In this way, Gravicells demonstrates a specific kind of wearable space in the sense that it creates a space of conjunction between body and space, space and technology. In wearable space, "space becomes wearable when embodied affectivity becomes the operator of spacing" (Hansen, 2006, 182). In this embodied space of depth, space is never preconditioned or predefined; space unfolds itself, as the affective body becomes an active partner in spatializing the space. There is a bi-directional movement. As the body becomes an active performer of the space, the space configures itself and further facilitates the bodily involvement in the spatialization process. The space of Gravicells thus brings about "the particular technical expansion of pre-personal bodily function that," according to Hansen (2006, 22), "digital technologies could facilitate".

By materializing the sensible connection between the body and the world through the technological integration of space, Gravicells succeeds in bringing to the fore in our embodied experience the shared space that usually remains visually empty, although it may be filled with air and numerous invisible particles. This supporting, connective space of the world is found in depth-depth that anticipates the crisscrossing or the embrace between the body and the world. Gravicells, as an architectural experimentation of the twenty-first century media, materializes the transformative process that emerges from the encounter that happens in depth. By sensibly materializing the ever-changing boundary between gravity and our bodily physicality, operational depth is brought to our attention. Gravicells thus presents itself as an experiential medium of depth. In this embodied space of depth, the potential interchange becomes sensible when the participant's bodily existence is interlaced with the world.

Throughout the process, Gravicells visualizes how space lies between the interactions of the body and its environment. It delivers a sense of how the dynamic encounter happens in depth by actualizing the bodily spacing in a multi-sensorial manifestation. In this process, Gravicells succeeds in expanding the range of human sensibility: participants are able to discover an imperceptible dimension of the world. Cited in Spielmann $(2012,6)$, Mikami states: "In this artwork, it is possible for us to develop a new human sense through feeling gravity differently than usual and having a new perception of body. The work provides a space with hypothetical dynamics having the opposing forces of gravity and resistance, through special devices and sensors. Walking freely in the site, visitors are able to feel gravity that they are seldom aware of, resistance to it, and the effects caused by other participants." By expanding the horizon of environmental 
sensibility, Gravicells also broadens and expands the human ability to actively participate in the world. In this way, the work offers an immediate experiential access to the operational depth that usually remains outside the scope of our everyday perception.

\section{REDISCOVERING THE HIDDEN DIMENSION OF DEPTH AS THE SOURCE OF REVERSIBILITY}

In "Eye and Mind," Merleau-Ponty $(2007,135)$ articulates depth as the first dimension that lies at the center of the flesh of the world. MerleauPonty was confronted by the enigmatic bond between the near and the far as depth connects things by separating them; "it is flesh as a distance that brings with it proximity" - proximity through distance. He therefore acknowledges that depth is paradoxically a revelation of concealment; it is the source of reversibility. The reversibility that is inherent in -and a manifestation of- depth is well explained by Steinbock $(1987,340)$ : "[Depth] is the 'rift' disengaging and engaging figure and ground, the "cleavage' by which they oscillate, they interplay." Cataldi $(1993,3)$ also explains: "depth is not simply the 'background' and neither is it simply a 'hidden dimension.' It is best understood as a source of 'reversibility,' as the process that generates that backgrounding of the foreground and that foregrounding of the background we can perceive whenever we perceive one or another of the ways in which ambiguous figures can come to the fore or unfold." The relationship between the foreground and the background in depth is inherently reversible simultaneously with movements.

Enveloping movements, depth also opens up across time and space. In Gravicells, the virtual boundaries between bodies and space are unstable and relational. While each body always relies on its own spatiality, the spatial configurations of the body are subject to change as the body enters into relationships with other bodies as well as changing its velocity and direction. In Gravicells, the sense of space emerges along continuous movements. Ströker $(1965,20)$ clarifies the space of movement that grounds the "primordial and intransgressible" inter-relationship between body and space: "Through my movement...space no longer remains what it was, but [it] is immediately transformed. In a reverse manner, I am not only a receptacle for its contents but a co-carrier, and first of all a shaper of its atmosphere through my movements." In Gravicells, body and space become both sensible and sensing, and their relationship is reversible as their boundaries only become distinguished when they are inter-implicated. As the body moves, hidden spatial elements are exposed, and the body and the space work together to create certain spatial patterns or relations. In this experience, as the body moves, depth is given a "temporal extension" that accompanies the movement.

As noted in Merleau-Ponty (1968)'s own comments, Straus (1966) offers a foundation for the spatiotemporal structure of depth. In his short essay, “Distance as a Spatio-Temporal Form of Sensing," Straus (1966) argues that distance (that comprises depth) is not only spatial but also, more importantly, temporal, as it is an overarching medium that includes an observer's body and movement. He explains: "In sensory experience, space and time are not yet separated into two fixed forms of intuition. Distance is not merely the spatiotemporal form of sensing, but is as well, the spatiotemporal form of living movement" (Straus, 1966, 284). For Straus, distance correspondingly escapes the arena of visual abstraction and is 
brought into the dynamic life world in which the mobile and sensing body moves and senses. It is a sensible space of movement that extends both spatially and temporally. Not only space, but also "time emerges within depth" (Mazis, 2012, 229).

Massumi (2008) suggests that we should revise our understanding that form is ever fixed and instead realize that it involves movements in our sensing of the world. When we see an object, what is seen is a dynamic relationship between what is invisible and what is visible. For example, the volume of a 3D object is immediately perceived without seeing its invisible backside. Any form that is sensible can never be fixed and is only completed in a dynamic relationship between the visible (the actual dimension) and the invisible (the virtual dimension). The interplay between the invisible and the visible is what precisely manifests depth. We never perceive a thing as fully present all at once; rather, things are present through limited perceptual aspects that can be revealed and hidden according to the positions of a moving body. As the body moves, the hidden elements are exposed, and these cues work together to create certain spatial patterns or relations; the reversibility is activated. The moving and sensing body is what creates its own spatial level thus perceives the space. As the body moves, depth is given a "temporal extension" accompanied by the movement. This is different in essence from the traditional account of depth that does not imply the possibility of change through movement. Unlike traditional depth in which a hidden surface can only "be recalled, imagined, conceived, or perhaps known, but not perceived," (Gibson, 1979, 80) Gibsonian depth spatializes in its temporality and involves "the transformation of near sides turning into far while far sides are turning into near." (Gibson, 1979, 84) This observation on depth is well articulated by Merleau-Ponty $(1968,309)$, explaining a field of presence extending in two dimensions: "The here-there dimension and the past-present-future dimension. The second elucidates the first." Space becomes accessible only when we understand it as temporal. In MerleauPonty's (1968) understanding, space and time are two dimensionalities of the "flesh" of the world rather than two separated entities; there is a reciprocal insertion and intertwining of one in the other. This intertwining of space and time can only be perceptually accessed through subjective (or interior) experience.

While the work materializes the entanglement of time, space, humans, and technology to create an experience of the complex present in the structure of depth, it also reminds us that we are objects embodied in the larger system of the world. The collected data of the participants' movements are measured by GPS, and the locational data is simultaneously projected on the wall in visual forms. This process allows participants to see themselves as moving bodies that collectively create the sense of space. The binary structure of subject and object becomes blurred as the sense of self in mobility is driven by the point of seeing and being seen. Each moving body is continuously represented as locational data embedded in the world with a GPS position that is also dependent on the earth's movement. However, this practice differs starkly from other media practices that try to enframe users in computational networks, wherein their bodily experiences are reduced to mere data. The "objective" space of data representation as measured by GPS is continually deformed though incrementally added data as people move in Gravicells; the actions take place in the site crisscrossing the real and virtual space. Rather than reducing bodies to mere observable points in the data network, Gravicells is fully committed 
3. According to Couchot and Hilaire (2004, 153), while "first[-order] interactivity understood human-computer interactions on a stimulus-response or action-reaction model," focusing on the control of communication, second-order interactivity deals with notions of "self-organization, emergent structures, networks, adaptation and evolution."

4. Maturana and Varela (1980) coined the term "autopoiesis," the reflexive feedback mechanisms in living systems. An embodied life is an open system that individuates itself in its relation to an environment. to reinvigorating the experience of the present by achieving second-order interactivity (Couchot and Hilaire, 2004)(3). The representational space of the data is transformed according to the participants' movements while directly impacting their movements in return; it extends both the human and the machinic autopoietic capacity, making the levels of interaction much more complex (Maturana and Barela, 1980) (4). In this way, Gravicells further achieves a larger technological enlargement of the present by deliberately creating connections between the site of the experience and the virtual space of the data.

Gravicells offers an architectural experiential platform for understanding depth by reinvigorating the primary dimension of the living present. Gravicells thus offers an immediate experiential access to the operational depth that usually remains outside the scope of our everyday perception. While a variety of technological space productions are claimed to compress the experiences of time and space, getting rid of the sense of depth and providing access to virtual content from any place and any time, Gravicells focuses on what it means to be in the messy and physical world. Gravicells facilitates an interruption of the technical speed that is driven by industrial technology through a correlative deepening of the spatiotemporal experience, bringing our focus to the operation behind experience, which is only possible through the encroachment of bodies and environments. Depth, as the flesh of the world, suggests an encroachment between all beings, in accordance with the vectors of an ever-deepening linkage between them. The acknowledgement of operational depth in addressing experiences facilitated by Gravicells allows us to understand the spatialities of bodies and their implication in the vaster worldly spatiality. More importantly, as a dynamic critical spatial practice, taking place in the expanded field of art, architecture and technology, the work affords experiential access to the virtual dimension of space. Gravicells operates as an experiential medium that is productive of sensibility that makes the dimension of depth palpable. In turn, acknowledging the operation of depth as the primordial spatiality of the world is crucial as it allows us to reveal the potential of the twenty-first century media. Most previous media interactions are limited to place humans within computational networks where bodies are quantified and calculated, thus registered by the systems. As a practice of the expanded field of art, architecture, and technology, however, Gravicells directs our attention to the flesh of the world that encrusts bodies. They work toward reinvigorating the primary dimension of living present that is deeply grounded in the operation of the world. Thus, the study of depth in the twenty-first century media art and architecture offers a way to access to the critical characteristic of contemporary technology that reinforces the intrinsic inter-relationship between human experience and environments.

\section{BIBLIOGRAPHY}

CATALDI, S. L. (1993) Emotion, Depth, and Flesh: A Study of Sensitive Space, State University of New York Press, Albany.

EINSTEIN, A. (1920) Time, Space, and Gravitation, Science, 51 (1305), 8-10.

GIBSON, J. J. (1979) The Ecological Approach to Visual Perception, Houghton Mifflin, Boston.

GROSZ, E. (2001) Architecture from the Outside: Essays on Virtual and Real Space, The MIT Press, Cambridge. 
HANSEN, M. B.N. (2004) The Time of Affect, or Bearing Witness to Life, Critical Inquiry, 30, 584-626.

HANSEN, M. B.N. (2006) Bodies in Codes: Interfaces with Digital Media, Routledge, New York.

HANSEN, M. B.N. (2012) Ubiquitous Sensibility, Communication Matters: Materialist Approaches to Media, Mobility and Networks, eds., J. Packer, S. B. Wiley, Routledge, New York.

HANSEN, M. B.N. (2015). Feed Forward: On the Future of The twenty-first Century Media. University of Chicago Press, Chicago, London.

HAWKINS, H. (2014) For Creative Geographies: Geography, Visual Arts and the Making of Worlds, Routledge, New York.

MASSUMI, B. (2006) The Parables of the Virtual, Duke University Press, Durham, NC

MASSUMI, B. (2008) "The Thinking-Feeling of What Happens." Inflexions 1. "How is Research-Creation?" [www.inflexions.org]

MATURANA, H. and VARELA, F. (1980) Autopoiesis and Cognition: The Realization of the Living. D. Reidel Pub. Co., Dordrecht, Holland; Boston.

MAZIS, G. A. (2012) Merleau-Ponty's Artist of Depth: Exploring “Eye and Mind" and the Works of Art Chosen by Merleau-Ponty as Preface, PhanenEx 7 (1).

MERLEAU-PONTY, M. (1962) Phenomenology of Perception, trans. C. Smith, Routledge, New York.

MERLEAU-PONTY, M. (1968) The Visible and The Invisible, trans. C. Lefort, Northwestern University Press, Evanston.

MERLEAU-PONTY, M. (2007) Eye and Mind, The Merleau-Ponty Reader, eds. T. Toadvine, L. Lawlor. Northwestern University Press, Evanston.

NEWTON, I (1642-1727) The Principia : mathematical principles of natural philosophy, ed., A. Koyré, I. B. Cohen, Harvard UP, Cambridge, MA.

OVERDUIN, J. (2007) Einstein's Spacetime, Gravity Probe B: Testing Einstein's Universe [https://einstein.stanford.edu/SPACETIME/ spacetime2.html] Access Date (23. 02. 2016)

RENDELL, J. (2006) Art and Architecture: A Place Between, IB Tauris, London.

RENDELL, J. (2008) Space, Place, and Site in Critical Spatial Arts Practice. The Practice of Public Art. eds. C. Cameron, S. Willis, Routledge, London; 33-55.

SPIELMANN, Y. (2012) Perceptual-responsive environments: sense and sensibility in Japanese media artist Seiko Mikami's installations, Journal of Aesthetics \& Culture, 4.

STEINBOCK, A. J. (1987), Merleau-Ponty's Concept of Depth, Philosophy Today. 31 (4).

STRAUS, E. (1966) Phenomenological Psychology: The Selected Papers of Erwin W. Straus, trans. E. Eng, Basic Books, New York. 
STRÖKER, E. (1965) . Investigations in Philosophy of Space. . trans. A. Igis Mickunas. . Ohio University Press, Athens.
Alınd1: 26.09.2016; Son Metin: 17.04.2017

Anahtar Sözcükler: Genişletilmişs sanat alanı; mimarlık ve teknoloji; yirmibirinci yüzyıl medyası; alternatif mekansallık; derinlik; fenomenolojik yeniden yapılanma.

\section{DERİNLİĞİN MIMMARİİ: 21. YÜZYILDA KRİTIK BİR MEKANSAL PRATIK OLARAK GRAVICELLS}

Bu makale, Seiko Mikami ve Sota Ichigawa`nın yaptığı, Gravicells'in (2004) kapsamlı bir analizini, uzay zaman deneyimlerimizin sanal boyutlarını somutlaştıran bir 21. yüzyıl medyasının mimari deneyleri olarak sunmaktadır. Bu proje, mekânın alternatif deneyimleri üreten deneysel arayüzler olarak çalışan sanat, mimari ve teknoloji arasındaki örtüşme noktaları ve işbirliği alanlarına yönelik bir disiplinler arası çalışma alanındaki çalışmanın etrafında konumlanmıştır. Bu makale özellikle, mekân algısının ardında kendini ilkel mekânsallık olarak açığa çıkaran sanal işlemleri incelemekte ve bedenler ile mekânların birbirine bağlanmasını Gravicells ile kurulan duygusal etkileşime dayandırmaktadır.

Katılımcıları, yerçekimi ilişkilerini görselleştiren veriye doymuş bir ortama davet eden Gravicells, mekânın ve katılımcının bedeninin gerçekten birbirine bağlılığına ve zaman ve uzaydan münezzeh bir mekân algısına dair duygusal bir deneyim sunmaktadır. Gravicells'in somut deneyimine içkin olan bu karmaşık mekan-zamansallığı açmak için bu makale, derinlik kavramının görüngüsel bir yeniden yapılandırılmasını sunmaktadır. Derinlik kavramının akademik ve basmakalıp gösterimlerine meydan okurken ve kavramın hem mesafe hem de hacimselliği içeren görüngüsel boyutunu yeniden yapılandırırken; uzaklık, özne ve dünya arasındaki

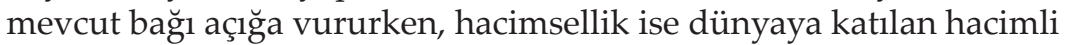
bedenlerin olasılığını belirten atmosferik boyutu tanımlamaktadır. Hem öznenin kaynağı hem de öznenin dünyada sarılması için bir araç olarak derinlik, en iyi, beden, zaman ve mekân arasındaki sürekli etkileşimi temel alan genel çevre veya birincil koşul olarak anlaşılır. Bu çalışmada, derinlik, artık iki boyutlu retinal görüntülerden dolaylı olarak çıkarılmış soyut bir geometrik mekân olarak değil, dünyanın eş-varlığını temel alan birincil mekânsal ortam olarak ele alınmaktadır. Gravicells, derinlik kavramını somutlaştırarak, mekân duygusunu radikal bir şekilde yeniden şekillendirmekte ve kendimizi yaşadığımız çevre ve diğerleri ile ilişkili olarak tanımlama biçimimize dair anlayışımıza zemin kazandırmaktadır.

\section{ARCHITECTURE OF DEPTH: GRAVICELLS AS A CRITICAL SPATIAL PRACTICE IN THE $21^{\text {ST }}$ CENTURY}

This essay provides a comprehensive analysis of Gravicells (2004), by Seiko Mikami and Sota Ichigawa as an architectural experimentation of the twenty-first century media that materializes virtual dimensions of our spatiotemporal experiences. This project explores points of overlap and spaces of co-operation between art, architecture and technology that operate as experiential interfaces generating alternative experiences of space. In particular, this essay examines virtual operations behind the perception of space that reveals itself as the primordial spatiality 
grounding the interconnectedness of bodies and spaces through affective engagement in Gravicells.

By inviting participants into a data-saturated environment that visualizes gravitational relations, Gravicells offers an affective experience of the intrinsic interconnectedness of the space and the participant's body as well as a sense of space that opens up across time and space. To unpack this complex spatiotemporality of the embodied experience of Gravicells, the essay provides a phenomenological reconstruction of the notion of depth. Challenging academic and conventional designations of the notion of depth and reconstruct its phenomenological dimension that comprises both distance and voluminosity; distance reveals the immediate link between the subject and the world, while voluminosity describes an atmospheric dimension that indicates the possibility of voluminous bodies involved in the world. As both an origin and a means of enveloping the subject in the world, depth is best understood as the general milieu or primary condition that grounds the continuous inter-implication between body, time, and space; depth supports their envelopment, while they are fundamentally all structured in depth. In this study, thus, depth is no longer treated as an abstract geometrical space that is indirectly inferred from two-dimensional retinal images but as the primary spatial medium that supports the coexistence of the world. By materializing the structure of depth, Gravicells radically reframes the sense of space, and surfaces our understanding of the ways in which we define ourselves in relation to others and environments.

JUNG EUN CHOI; BA, MA, PhD.

Received her BA in German and English Literature (2004) and the graduate certificate in Art Theory and Criticism (2006) from Hongik University, Seoul, USA. Earned her MA in Visual Culture Theory from New York University, NY, USA (2009) and her PhD in Art History and Visual Studies and the graduate certificate in Information Science and Studies from Duke University, Durham, USA (2016). Her major research interests include contemporary art and technology, architectural media installations, and global visual culture. jung.choi@duke.edu 